\title{
The Characteristic Features of the Academic Fiction Genre
}

\author{
Syuzanna Poghosyan \\ Yerevan State Linguistic University
}

Z nglish - American Academic novel became one of the dazzling appearances

of the XX-XXI centuries. While searching for a good explanation to this fact we come across a chain reaction. Firstly, there comes the baby-boom after both of the WW-s which in its turn means an incessant growth of the world population in general. Then there appears the problem of WW veteran employment. "Even Welch, in an unwonted display of compassion, remarks that 'It's only to be expected, after a war' that young men should find it difficult to settle into a job" (Amis K. "Lucky Jim", pp x-xi ). Therefore academic institutions (as all other institutions) are both expanding and increasing in number in order to educate and employ the growing population. In their turn the problems more or less often occurring inside the academic walls also begin to multiply rapidly. Academic novels describe life situations in which moral characteristics of the heroes are disclosed and tested. They touch upon many human values. The appalling and miserable fortunes of the main heroes of the novels reveal the ailing life atmosphere where many social and personal problems come into view. Thus the foremost aim of the Academic novel genre is to introduce the various new themes which are closely connected with the small but autonomic campus world. Hence the adequate criterion according to which a novel may be classified as belonging to this genre is the following: an Academic novel is a work of fiction the primary thematic concern of which is closely related to the world of higher education. However this is not a static but quite young and yet rapidly developing genre.

This genre was founded somewhere in 1950-s, when in 1952 "The Groves of Academe" by Mary McCartney and "Lucky Jim" by K. Amis were published. They were and still are followed by many talented writers. The most celebrated among these writers are: Malcolm Bradbury, Mary McCartney, Phillip Rote, Alison Laurie, John Maxwell Coetzee, Francine Prose, etc. They keep in step with the times, introducing a whole range of problems that arise from student-teacher-family relationships. With the help of invented people and places these authors bring up and discuss real-life situations and the hottest problems nowadays.

For an accurate description of the genre we have looked through many articles, dictionaries and encyclopedias. The theoretical criticism of the genre is based on the great contribution made by such experts of academic fiction as Mortimer Proctor, David Bevan, Ian Carter, Wolfgang Weiss, Janice Rossen and Kenneth Womack. In particular M. Proctor has done a considerable work in his book "Reform and the University novel" where he gave the early literary portraits and the decline of Oxford and Cambridge as two of the oldest universities in the world with well-developed and complicated traditions and peculiar characters among both lecturers and students. In 
Chapter IV of the same book the author discussed the University novel itself which is a narrower branch of the Academic fiction genre (Proctor 1977:11-66; 150-203).

Such literary commentators and theorists as Elaine Showalter, John Lyons, Malcolm Bradbury, David Lodge and others suggested the classification of the Academic novels. For example, while constructing the history of the genre David Lodge suggests distinguishing two variations of Academic novel. American university novel becomes known as a Campus novel, while the British variant is known as a Varsity novel. This is due to the mere fact that campus is purely American phenomenon. Besides, a Varsity novel concentrates mainly on the student-student relationships, while a Campus novel depicts the student-lecturer relationship. But very little is done in the sphere of defining the borders of the genre as well as its characteristic features. Thus, while defining the features of the genre we will refer to four famous novels, namely: K. Amis's "Lucky Jim" (1952), Malcolm Bradbury's "The History Man" (1975), J. M. Coetzee's "Disgrace" (1999) and F. Prose's "Blue Angel" (2000).

Kingsley Amis (1922-1995) born in London was a cultural democrat that valued honesty, civility and the lack of pretense. His friends and colleagues described him as great storyteller and a genuine comic writer. He became the founder of the Academic fiction genre by his brilliantly funny novel "Lucky Jim" (1952). It is about the stuffy, provincial bourgeois world into which Jim Dixon - the main hero of the novel - is promoted .... and against whose values and codes he rebels..." (Amis 2002:viii-ix). Jim Dixon finds it very difficult to settle down after returning from the WWII. He starts to lecture at one of Britain's new red-brick universities. The novel describes his rather difficult relationships with the chair head, his students and colleagues. "Jim is ill-at-ease and out of place in the university because he does not at heart subscribe to it's social and cultural values, preferring pop music to Mozart, pubs to drawing rooms, non-academic company to academic. Looking into the face of a not particularly attractive bar-maid ... 'he thought how much he liked herand had in common with her, and how much she'd like and have on common with him if she only knew him", by David Lodge (Amis 2002:xi). To tell the truth Jim hates his job and especially Mr. Welch - the chair head - because the latter often organizes music parties and appreciates only those who can sing madrigals or play musical instruments. At one of such musical evenings Jim meets Welch's son Bertrand and his girlfriend Christine. A very deep and sincere feeling towards Christine changes Jin completely. He understands that he needs to find his place in this life and must fight for his happiness. In the end he gets a good job offer and his beloved woman.

Malcolm Bradbury's (1932-2000) "The History Man" (1975) introduces the age of "glass and steel" universities which came to substitute the old red-brick buildings. On the one hand, these new buildings were very cheap and easy to build but on the other hand, they lacked the warm and cozy academic atmosphere which is very essential for a successful academic process. The novel introduces the Kirks - Howard and Barbara. The reader witnesses the rapid metamorphosis of this family which leads to Barbara's 
suicide at the end of the novel. This suicide proves that the so called society development in the novel was going in the wrong direction.

John Maxwell Coetzee was born in Cape Town, South Africa, in 1940. Coetzee has gained many awards throughout his career, although he has a reputation for avoiding award ceremonies. He was the first author to be awarded the Booker Prize twice. On 2 October 2003 it was announced that he was to receive the Nobel Prize in Literature, making him the fourth African writer to be so honored. The press release for the award also cited his "well-crafted composition, pregnant dialogue and analytical brilliance," while focusing on the moral nature of his work. Coetzee's "Disgrace" (1999) is about a 52-years-old Professor David Lurie who is divorced. At this age he is still filled with desire but lacks the passion. An affair with a student leaves him jobless and homeless. His friends and colleagues turn away from him and he embarrassingly retreats to his daughter's smallholding. The complicated racial complexities and the Apartheid policy (a system of legal racial segregation enforced by the National Party government of South Africa between 1948 and 1994, under which the rights of the majority 'non-white' inhabitants of South Africa were curtailed and minority rule by white people was maintained) caused an incident of terrible violence which smashed the only remaining relationship and made the father and the daughter confront each other.

Francine Prose was born in 1947, in Brooklyn, NY. Prose uses a rather simple and laconic language, brings up urgent and up-to-date social, political and other issues. Prose's novel "Blue Angel" (2000) became the winner of the National Book Award. This book is about a man's crashing journey towards new life. Professor Swenson teaches creative writing at Euston College. Once a quite successful writer at present he is choking in the lifeless and themeless atmosphere of an academic town. The situation gets even worse because it's been quite long since any of his students have shown promise. And poor Professor realizes that it's impossible to teach talent. Talent is something divine and given from the birth. Thus it can be developed but never taught. Right at that moment a pierced and tattooed girl named Angela Argo enters his class. She seems to possess a rare talent for writing. She pretends needing his help desperately. But when Swenson fails to fulfill her high intentions she tramples him into mud. This novel shows best what happens when academic politics collides with political correctness.

The authors of this genre put a special accent on the theme of the "lost generation". After the World War II the situation repeated the one after the World War I: people and especially youth lost their faith in future and lived mainly by the day. On the other hand, they desperately wanted to taste all the pleasures of the life as quick as possible since the life proved to be very fragile and short. Professor Welch's son Bertrand courts Christine bearing in the back of his mind totally different intentions: namely, Bertrand's expectations are to get a well-paid job at her uncle's office. Here it needs to be clarified that in the later novels other wars, not necessarily as great and consuming as the WWII, left the same influence on people making them act in the way which can be harmful for others. Here are also included such "wars" as the ones 
between males and females, blacks and whites. Wars in general teach people to become absolutely egoistic and not to care about building or preserving relationships. Therefore, without any remorse people generally made use of others just like things and gave them up as soon as there was nothing to expect from them. This was the case with both Angela Argo and Melanie Isaacs. The first girl is the main heroine of the novel "Blue Angel" by Francine Prose. Angela uses her teacher to achieve her dream to become a writer and when she sees that he is not strong enough to represent and stand up for her, she trashes him. She resembles one of the Amazons (a nation of all-female warriors in Classical antiquity and Greek mythology. No men were permitted to have sexual encounters or reside in Amazon country. But once a year, in order to prevent their race from dying out they visited the Gargareans, a neighboring tribe. The male children who were the result of these visits were killed, sent back to their fathers or exposed in the wilderness to fend for themselves; the females were kept and brought up by their mothers, and trained in agricultural pursuits, hunting, and the art of war. In other versions when the Amazons went to war and they brought some men as slaves, and once or twice a year they would have sex with their slaves.) who cunningly called in men to their island, used them and then cold-heartedly killed their lovers. As for Melanie Isaacs, she is the heroine of the novel "Disgrace" by J.M. Coetzee. She manipulates with her Professor's feelings at first to get a shelter, then - a passing grade on his subject. Melanie "sells" her body for a passing mark and is rather shaken by surprise when her professor tries to make her take the test by all means. "She stares back at him in puzzlement, even shock. 'I am no longer just a student' How can you speak to me like this? 'I can't take the test' She raises her chin" (Amis 2002:34-35) and leaves not dignifying her professor with a reply. Her act of laying a charge of sexual abuse is kind of revenge, as well as an opportunity to get rid of an unhelpful person.

The foremost characteristic feature of the genre is the following - the university with its routine and people becomes the corner stone of the novel. Sometimes the university itself is described in detail and becomes a novel character. M. Bradbury leads the reader of his novel through the campus speaking about every corner of the University of Watermouth. This tour around the university campus has a special purpose - to show the ugly cold and dull atmosphere in the new "glass and steel" buildings. It is rather cheap, easy and fast to build them. "...They grow everywhere like mushrooms after the rain" (Bradbury <www. Modern Lib.Ru/Современная проза/Брэдбери МАлькольм Стэнли/Историческая личность>). But they lack the warmth and hospitability. There is no proper academic atmosphere in those glass and steel buildings.

For another group of novels the campus description and its history somehow foretell the further development of events. In the novel "Blue Angel" the narration starts with the history when, how and why Euston College was built. "Elijah Euston founded Euston Academy to educate his ... sons and daughters... Three daughters died from diphtheria, two more committed suicide. ... the campus is haunted by the ghosts... the spirits with an appetite for the souls of undergraduate women" (Prose 
2000:14-15). Other Academic novels introduce the university by telling much about the students and the staff, depicting the deeds and the struggles that different characters of the novel go through. These characters are portrayed with such genuine skill that they seem very realistic and lively. The authors use them to reflect problems of reality; on the one hand these characters receive such precise psychological features and shading that they seem quite real and concrete; on the other, they become a collective characters for the very human kind. Let's take as an example Professor Welch (Amis 2002). Right at the beginning of the first chapter rather clear physical description of the man is given: professor Welch is "...tall and weedy, with limp whitening hair..." (Amis 2002:8). The quotation brought above helps to draw a clear portrait of a man. But while one continues reading the novel the professor begins to obtain the features of a person who is truly unsuitable for the position he occupies. As a department head Welch requires that everybody fullfils their professional duties as well as it is possible, but he himself does not set a good example and isn't a helpful supervisor either. As a matter of fact he makes Dixon deliver a lecture according to the normative, even though Dixon is neither ready for that challenge nor he feels inclined to do that.

The first Academic novels contained much irony. "Lucky Jim" is a classic comic campus novel. One of the most famous contemporary literature critics David Lodge declared this book as "A novel that changed a generation" (Amis 2002:V). In his hilarious send-up of academic life, K.Amis poked devastating fun at a very British way of life, and gave a post war fiction a new and enduring figure to laugh and laugh at. Although there are a lot of places in the novel where we are invited to chuckle, there are also passages which describe precisely many sad aspects of the present-day life. As for the comic feature of the novel, it needs to be said that the comedy in the novel derives from two sources: the comedy of situation and the comedy of style. The comedy of situation is inseparable from the style. In other words, the situation causes laughter when it is described in a comic language. Whereas the comedy of style is based purely on the way language means and stylistic devices are used. And in this case there is neither situation nor action. Amis's comedy introduced a new tone into English fiction. It has some traditional elegance. On one hand it is very educated, on the other - rather classless. Amis's vocabulary is rich and juicy. The author brings some freshness to the satirical observation of everyday life. Then $\mathrm{K}$. Amis's light and juicy irony developed into dark satire in the novel "History Man" by M. Bradbury. This novel belongs to the second time-period of the historical development of the academic novel genre. Therefore it is full of dark satire. In the very beginning of the book it is described how the Kirks awaken each day and run to the window and examine steadily the skies to see if some dark hands, or thunders sent by gods or some dark horsemen had appeared to announce at last the birth of a new and better world. (Bradbury <www. ModernLib.Ru/Современнаяпроза/БрэдбериМАлькольмСтэнли/Историческая личность >) 
At present we see a tight mixture of satire and tragedy. If we analyze the disgraceful situation in which Professor David Lurie finds himself after being fired from Cape Town University is both comical and tragic. Once a respected professor, David now has to give up all his high ambitious intensions to write an opera on Byron's stay in Italy and become a humble peasant and a dog-man. And due to the political and social changes in South Africa David becomes a helpless and invaluable social unit. J.M. Coetzee like other authors does not and even cannot directly describe own feelings and thoughts about political and social issues. So, the author "hides" himself behind the heroes. The reason is that the true art cannot be enclosed in the narrow boundaries of oneself.

The genre of Academic novel has a unique type of the novel hero. The hero is a very highly intellectual person and therefore finds it very difficult to fit into the university sphere. This is the reason why these characters are totally unable of co-existing with the rest of the campus society. This hero does not see that he has chosen a wrong life path and it wears out his mental and physical strength. He starts to live like an automat. But life is a precious gift and it requires that one understands the value of each moment. That is why the hero is getting punished in order for him to realize that he does not have a right to simply waste time. All the main heroes form the above mentioned novels - Jim Dixon, Howard Kirk, Professor David Lurie and Professor Swenson - fit into this description.

There are few characters in the Academic novel. They are usually presented by opposing couples. This technique helps to increase the dynamics of the novel. All the heroes have their opposition. But the most interesting is the couple formed by the main hero and the trickster $(<$ http://abuss.narod.ru/texthtml/trickster.htm $>)$. The foremost aim of the trickster is destruction. The trickster helps to underline the positive features of the main hero. In some sense this so called trickster is the shadow of the main hero. If Professor Swenson is the main hero of the novel "Blue Angel" then Angela Argo is his trickster. Professor lives in some self-invented world. He fancies that he and Angela Argo can have something in common because she seems to him a talented writer. Furthermore he wants her to become a creative and ingenious coauthor of his imaginative world. But he is dreadfully mistaken because unlike him Angela uses her talent only to get fame, she doesn't find contentment and sole tranquility in writing like he does.

Just another characteristic feature of the genre is the ball/the evening party which seems to be the peak when the tension tightens most. It makes possible to gather all the characters of the novel together and create all kinds of bonds among them. It is during this party that all the professional and personal conflicts reach their highest point. A good example will be the party the Kirks throw at their house when different characters come in touch with each other to form and break relations. The warmth, coziness and alcohol help to relax and therefore reveal the true self of each character. Hence we get an opportunity to examine each person. And since each one represents a true human being we acquire an unlimited life experience in the sphere of human characters and relations. The annual university ball at a provincial university marks 
the turning point in Jim Dixon's life. He realizes that he is much fond of Christine and gathers strength to break up with Margaret and look forward to new life opportunities.

The next characteristic feature can be the new aspect in man-woman relationship. In the first novels these relationships involve only the university staff. For example, let us take Jim's relationship with Margaret and later with Christine. The next step to make the novels more dynamic and interesting - a sexual relationship between a professor and a female student - is considered. This kind of relationship emerges due to different reasons. Sometimes a male staff exploits his position. Just like in Professor David Lurie's case who probably not deliberately but consciously traps the young girl. He gives her a shelter and a passing mark just for the sake of being able to keep her by his side. Other professors, like Howard Kirk, imagine that by having an affair with their students they fulfill their responsibilities as tutors. And at last some pitiable weak persons like Professor Swenson fall in love with their students just because of the latter's remarkable writing talent.

It goes without saying that any writer in any times cannot neglect different sociopolitical urgent issues of his epoch. Therefore reading different novels of this genre one comes across problems of the XX-XXI centuries like plagiarizing, feminism, antifeminism, apartheid policy with its consequences, etc.

Summing up, we come to the following important reason why Academic novel has become one of the most meaningful happenings in present day Literature. It is because it has the widest intellectual-philosophical potential which opens new perspectives on how to solve problems in the sphere of man-society relationship. As a literary genre the Academic novel has already got several concrete features, namely: the university as the corner stone of the novel; an evening party or ball which brings the novel to its climax; the unique type of hero; the opposing couples which helps to increase the novel dynamics; ironic/satiric mood of the narration.

\section{References:}

1. Antsiferova, O. (2008) Universitetskii roman: zhizn i zakonizhanra. // Voprosy literatury, iyul-avgust. N4.

2. Bakhtin, M.M. (1986) Formy vremeni i khronotopa v romane. Ocherki po istoricheskoi poetike. // Literaturno-kriticheskie stat'i. M.: Khudozhestvennaya literatura.

3. Bakhtin, M.M. (1875) Voprosy literatury i estetiki. M.: Khudozhestvennaya literatura.

4. Genieva, Y.Y. (1979) Ne tipichnie i tipichnie angliiskie romany. // Inostrannaya literatura. $\mathrm{N} 8$.

5. Matthew, H.G.F. (1998) The British and American Academic Novel. The Professor romane: The Comic Campus, the Tragic Self. George Washington University Press. 
6. (2000) Oxford Advanced Learner's Dictionary of Current English. Oxford

7. Proctor, M.P. (1977) The English University Novel. Issue 15. Ayer Publishing.

8. Zhlutenko, N.Yu. (1988) Angliiskiy psikhologicheskiy roman XX veka. Kiev.

\section{Sources of Data:}

1. Amis, K. (2002) Lucky Jim. USA: Penguin Books.

2. Bradbury, M. (1976) History Man. Boston: Houghton Mifflin.

3. Coetzee, J.M.(1999) Disgrace. Penguin Books: USA.

4. Proctor, M. (1977) The University Novel. Issue 15.

5. Prose, F. (2000) Blue Angel. Harper Perennial.

6. <http://abuss.narod.ru/texthtml/trickster.htm>

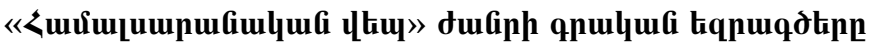

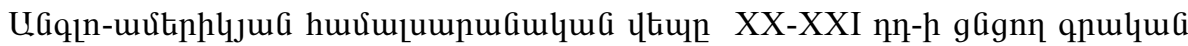



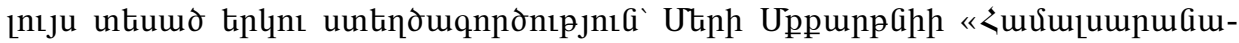

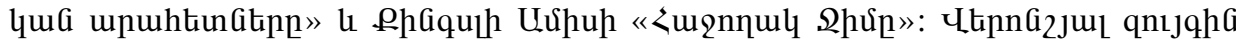

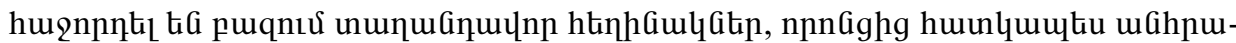

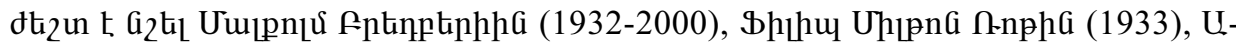

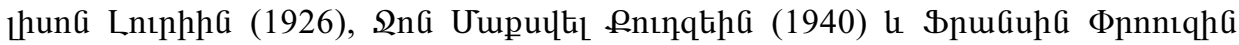

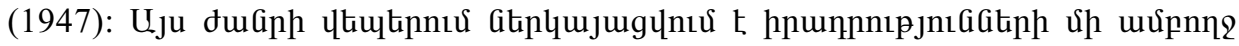

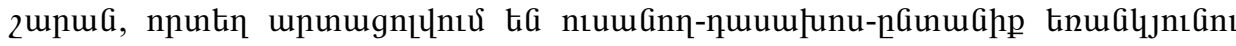

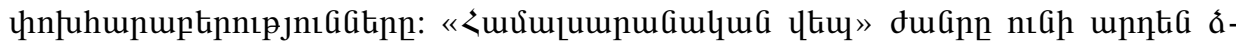

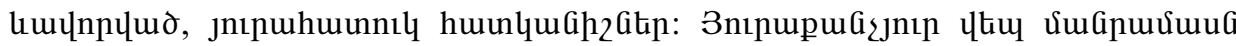

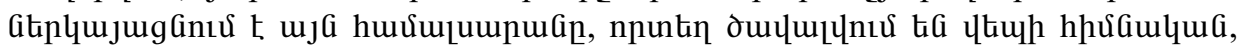

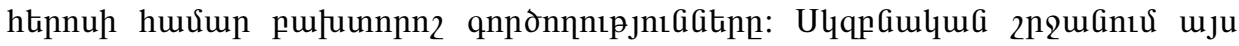

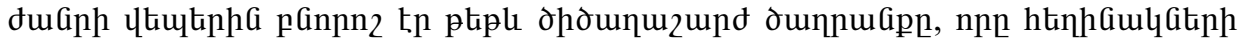

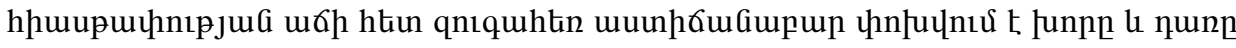

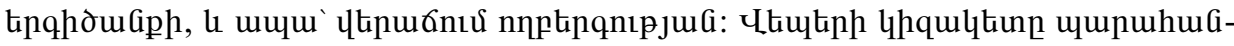



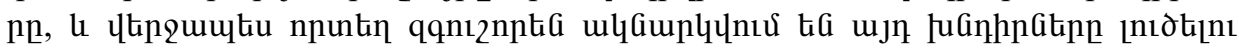
hGimpulnn unupptinulgitinn:



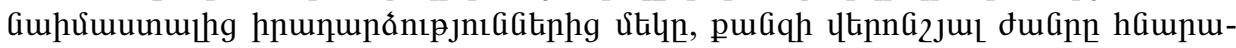

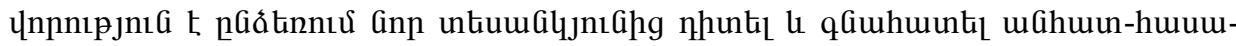
nulynıpjnı unntuhupuptinnıpjnıGitinn: 